\title{
A Dynamic Urban Lake Area Evolution Model Based on Multilevel Grid, Cellular Automata, and Multiagent System
}

\author{
Jianfeng Zhu $\mathbb{D}^{1}$ and Shenzhen Tian $\mathbb{D}^{1,2}$ \\ ${ }^{1}$ School of Geography, Liaoning Normal University, Dalian 116029, Liaoning, China \\ ${ }^{2}$ Centre for Human Settlements of Liaoning Normal University, Dalian 116029, Liaoning, China \\ Correspondence should be addressed to Shenzhen Tian; tsz999@lnnu.edu.cn
}

Received 19 June 2020; Revised 13 August 2020; Accepted 25 August 2020; Published 17 September 2020

Academic Editor: Jianhong (Cecilia) Xia

Copyright (C) 2020 Jianfeng Zhu and Shenzhen Tian. This is an open access article distributed under the Creative Commons Attribution License, which permits unrestricted use, distribution, and reproduction in any medium, provided the original work is properly cited.

\begin{abstract}
Urban lakes have been threatened by rapid expansion of cities in recent years. Their area changes could be extracted by remote sensing technologies. On this basis, a Dynamic Urban Lake Area Evolution Model (DULAEM) is proposed based on a multiagent system (MAS) and a cellular automata (CA) model. The DULAEM is integrated upon an Urban Lake Multilevel Grid (ULMG), which is composed of the vector model with the raster model. In the DULAEM, the CA layer is mainly used for modelling the interactions between urban lakes and their surrounding land use change through the activity of each cell; the MAS layer represents the actions of three typical human activities: government, real estate developers, and residents. These three agents have different actions in extent, strength, and priority according to their standpoints and functions. The CA layer and the MAS layer are both integrated upon the ULMG. Finally, a case study in Wuhan proves that the DULAEM can control the global relative error under $10 \%$. Therefore, the DULAEM is able to simulate the area change of urban lakes dynamically. It is significant for the policy-making of lake protection and the optimal configuration of land resources in the lakeside.
\end{abstract}

\section{Introduction}

Urban lakes are very precious freshwater resources for a city. They not only supply water for living and production but also play a significant role in regulating urban environment, storing flood, irrigating farmland, and beautifying the landscape of a city [1-5]. Thus, they are extremely valuable for urban development. However, the urban lakes have been greatly endangered by urbanization in recent years [6-8]. Lake area has been reduced $[9,10]$; water quality has been polluted $[11,12]$. This damage on the lakes is irreversible in some cases. For instance, many lakes disappeared completely from the map because of real estate development in Wuhan, China [13]. Therefore, it is meaningful to study the area change of urban lakes with urban development.

Lake area change is usually considered as the quantitative change of water resources. In traditional studies, a series of hydrological models were designed based on water balance equations. In other words, the change of water in a system equals the difference between the output and input of the system $[14,15]$. In recent years, some researches focused on the effect of urbanization and human activities on urban lakes. Damage to the lakes could be assessed by the water balance equation $[16,17]$. However, the traditional hydrological method needs a mass of historical data, usually hard to collect. On the other hand, in order to get higher accuracy, the hydrological models get very complex.

In addition, monitoring lake area change by remote sensing (RS) has been applied widely $[18,19]$. According to the spectral signature of water, lake area can be detected rapidly from remote sensing images by image processing methods [20]. The change of the lake area in different periods can be extracted by spatial analysis in geographic information systems (GIS) [21, 22].

In spite of the previous achievements, there is still a lack of knowledge about lake area change. Firstly, the study area in the previous studies was usually regarded as a particular lake watershed instead of all urban lakes. Secondly, 
monitoring lake area change by RS is a static method. It cannot show the process of the lake area change within a certain period of time.

This paper focuses on all lakes in a city. In order to find the pattern of the area change of these lakes, this paper used the method of urban evolution for reference. Particularly, cellular automata and multiagent systems were introduced to model the area change of urban lakes in a case study of Wuhan, China.

A cellular automaton (CA) is a kind of dynamical model with discrete time, space, and state. It is able to simulate the spatiotemporal evolution of a complex system by simple relationships between adjacent cells [23]. Cellular automata have been widely applied in mathematics, physics, biology, and complexity science, especially in studies of urban growth and land use and land cover change (LUCC) [24-27]. Urban lakes are a part of urban space geographically. So the area change of the urban lakes can be considered as a part of LUCC. In other words, urban lakes can be regarded as a subsystem of the urban system, which has been recognized as a complex system. Therefore, it is feasible to simulate the area evolution of urban lakes by cellular automata.

However, CA model cannot fully reflect the effect of urban development and human activities on urban lakes individually, because the neighbor relationships can only represent the interactions between the urban lakes and LUCC at lakeside. The various actions of human activities on the urban lakes cannot be ignored. For instance, governments can enact laws and regulations to protect the ecological environment of the lakes and their surrounding landscapes. On the contrary, real estate developers need more lands for building and developing. That could cause lakes to be filled in.

In order to overcome the limitations of the CA model, a multiagent system (MAS) was used to represent human behavior and decision-making. The concept of the agent is introduced from the areas of artificial intelligence (AI). An agent could represent an entity in reality that can make decisions independently $[28,29]$. A MAS model can be used for the analysis and simulation of complex systems. Especially in urban systems, MAS model has been applied extensively in many fields such as traffic, population, and economy [30, 31]. Combining multiagent system with cellular automata has become a trend at present in the studies of urban evolution and LUCC [32-35].

This paper aims to develop a Dynamic Urban Lake Area Evolution Model (DULAEM) based on MAS-CA model. In the DULAEM, the CA model is used to evolve environmental factors in the lakeside through the relationships between adjacent cells. MAS model is used to imitate human behavior and decision-making. Agents concerned with urban lakes in this paper include government agents, developer agents, and resident agents.

The CA model is usually based on a grid structure. A grid geographic information system (grid GIS) is very efficient for the spatial data and has been extensively applied in urban management [36-38]. However, the traditional data structures of a grid, such as vector and raster, cannot resolve the contradiction between high spatial resolution and efficient calculation. The raster model is simple and fast to access so that it is able to handle a huge number of grids and spatial analysis. Particularly, the raster model is efficient for cellular automata and searching neighbor cells. However, for discrete geographic features, such as urban lakes, the raster model is difficult to distinguish the grid cells of each lake. The vector model is more convenient than the raster model in computing lake areas. It would be extremely inefficient if the size of grids is small and the number of grids is massive. In order to overcome the defects of vector, Deren $\mathrm{Li}$ proposed the concept of Spatial Information Multigrid (SIMG), which consists of multilevel regular vector grids [39]. SIMG can improve the efficiency for searching a grid. However, the grid sizes at different levels are hard to be determined because the spatial scales of urban lakes are diverse. Still, SIMG offered an idea for modelling discrete geographic features with different spatial scales. On the basis of SIMG, this paper designed an Urban Lakes Multilevel Grid (ULMG), which integrated a regular structure with an irregular structure and combined the advantage of the vector model with that of the raster model [40].

\section{Materials and Methods}

2.1. Study Area and Data. In this paper, we focus on urban lakes in Wuhan City. Wuhan is one of the major cities in central China and is located in the middle reach of the Yangtze River. There are 13 districts as shown in Figure 1. The total area of Wuhan is $8494.14 \mathrm{~km}^{2}$, and the population is over ten million now. Since the 1990s, with the rapid development of the Chinese economy, Wuhan have been expanding sharply. Thus, the space of urban lakes had been compressed seriously by rapid urban expansion. For this reason, we extracted urban lakes of Wuhan during 1991 and 2002. During this period, Wuhan government had not yet set up a powerful supervision mechanism for surface water resources so that some urban lakes were filled in.

The urban lakes of Wuhan in 1991 and 2002 were extracted from Landsat TM/ETM + images. These images are composed of 7 spectral bands. The spatial resolution of each band is $30 \mathrm{~m}$. The lakes were extracted by Modified Normalized Difference Water Index (MNDWI). MNDWI is more accurate than Normalized Difference Water Index (NDWI) in the urban images, because MNDWI can restrain the noise of buildings [41].

The lakes of Wuhan in 1991 and 2002 are shown in Figure 2. There are 93 lakes. The area of each lake is more than $100,000 \mathrm{~m}^{2}$ in 1991. According to Figure 2, during 1991 and 2002, the area of 93 lakes had been decreased by $35.77 \%$, and ten of them had disappeared completely.

In addition, in order to assess the effect of LUCC at lakeside on the lakes, we made a $100 \mathrm{~m}$ buffer around the lakes. Land use in the buffer zones was extracted and classified into 5 categories in Table 1.

2.2. Urban Lakes Multilevel Grid. The fundamentals of ULMG are shown in Figure 3. The ULMG consists of twolevel grids. The first-level grid is irregular and adopts the vector model. The second-level grid is based on a square raster model. The grid in the second level is defined as the same size as the pixel of Landsat images. 


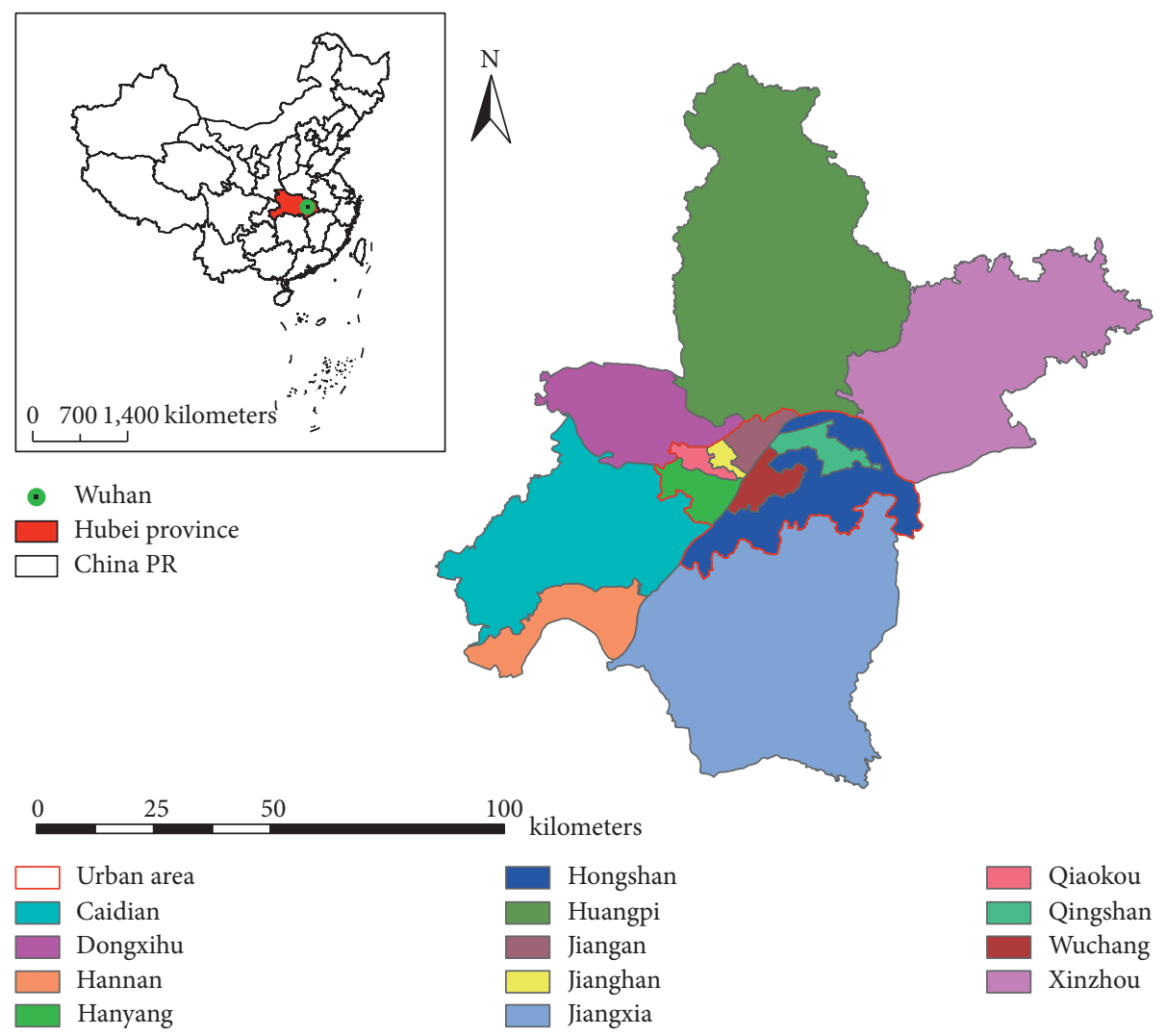

FIgURE 1: Location and administrative divisions of Wuhan City.

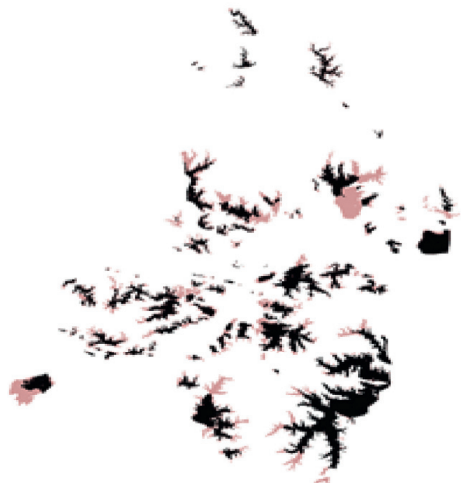

1991

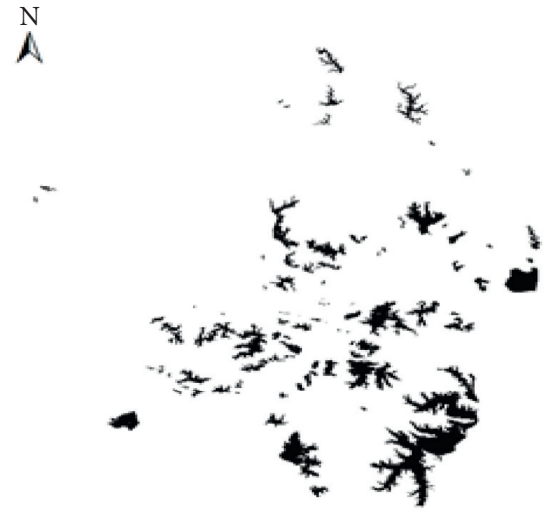

2002

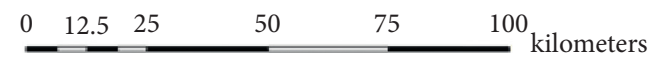

Urban lakes only in 1991

Urban lakes in both 1991 and 2002

FIGURE 2: Urban lakes extracted from Landsat images in 1991 and 2002.

TABLE 1: Land use classifications.

\begin{tabular}{lc}
\hline ID & Category \\
\hline 1 & Water bodies \\
2 & Agricultural land \\
3 & Vegetation \\
4 & Developed land \\
5 & Bare land \\
\hline
\end{tabular}

The second-level grid by raster model is generally stored and represented as a matrix. For this reason, the first-level grid is defined as the bounding rectangle of each lake rather than its real boundaries. In order to link two-level grids, there are several pieces of location information of each second-level grid in the attribute table of its corresponding first-level grid. The location information includes the following: 


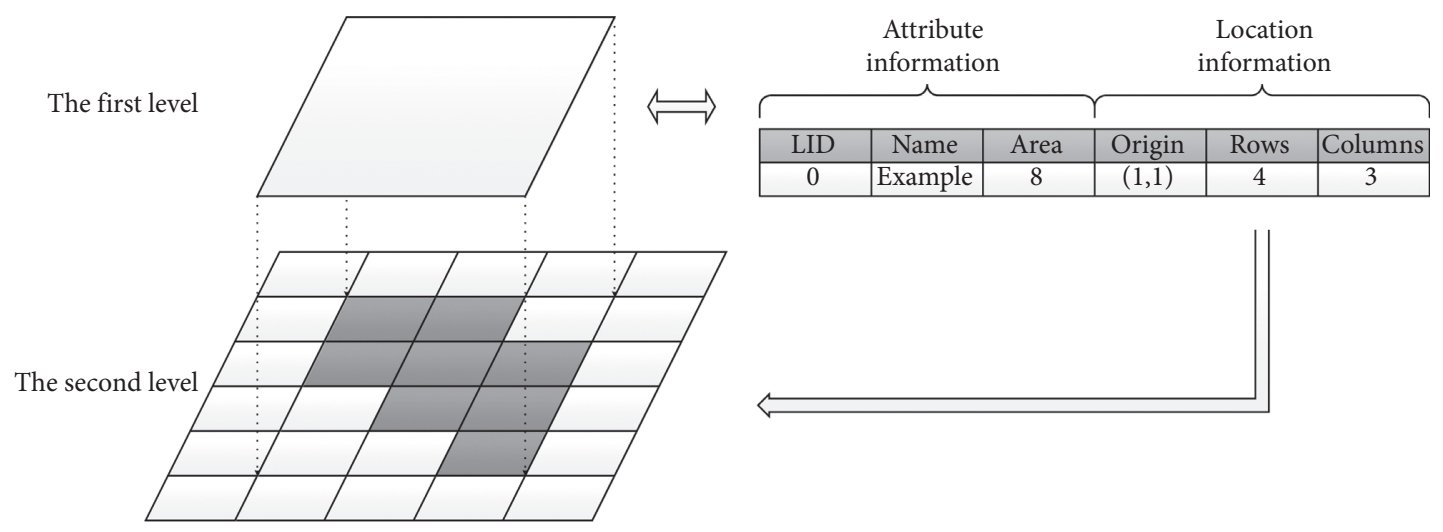

Figure 3: The rationale of ULMG.

(1) The row number and column number of the origin grid (from the upper-left corner).

(2) The numbers of rows and columns.

In addition to location information, some attribute information of each lake, such as lake ID (LID), lake name, and lake area, can be written into the attribute table of its corresponding first-level grid. On the other hand, each grid in the second level can only be represented by a pixel value that corresponds to the land use type of this grid with the ID number defined as in Table 1.

If the distribution of urban lakes is excessively dense, their bounding rectangles are likely to overlap with each other. In this case, the pixel value of each second-level grid is added before its LID. For instance, a pixel value of 2634 means that this second-level grid belongs to the No. 263 lake and its land use type is category 4 , developed land.

Figure 4 shows how to create the ULMG from Landsat images. The second-level grid can be acquired from images directly so that the spatial resolution of the second-level grid follows the images' at $30 \mathrm{~m}$. Before generating the first-level grid, the lakes extracted from images need to be transformed into the vector model. Finally, some parameters, such as the location information and LID, are added to the attribute table or pixel value to couple these two-level grids.

According to Figure 5, the ULMG of Wuhan is generated. There are 93 rectangles with different sizes, and some of them overlapped with each other. The second-level grid has 5529 pixels in height and 4789 pixels in width. In the case of East Lake, its origin grid (from the upper-left corner) is located on row 2915 and column 2224. There are 442 rows and 418 columns in second level. Consequently, the ULMG can make for fast access by the second-level grid based on raster model, because vector model would be inefficient if the total number of grids is over $10^{5}$. At the same time, the first-level grid based on the vector model could increase flexibility and reduce redundant data. The ULMG will lay a solid foundation for studying the area change of urban lakes based on cellular automata and multiagent systems.

\subsection{Dynamic Urban Lake Area Evolution Model.} Combining a CA model with a MAS model has been applied widely to the studies of urban expansion and LUCC. This

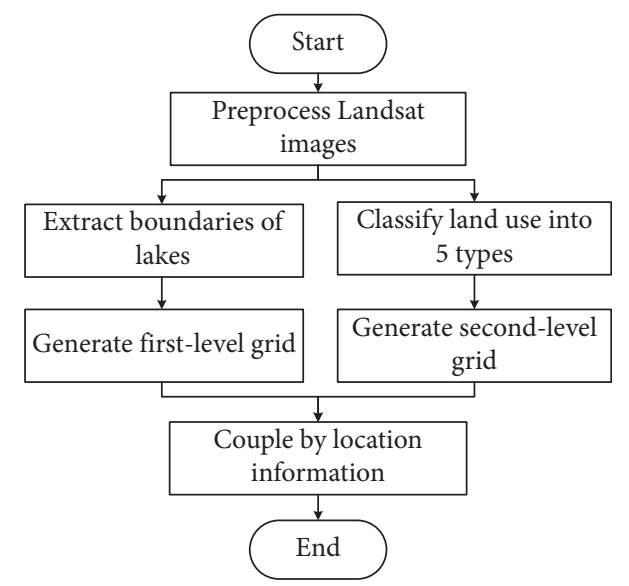

FIgURE 4: Generate ULMG from Landsat images.

paper uses the previous studies and methods for reference and designs a Dynamic Urban Lake Area Evolution Model (DULAEM) based on a CA model and a MAS model.

As shown in Figure 6, there are two layers in the DULAEM. CA layer is in the bottom to model interactions between urban lakes and their surroundings. On the basis of a CA layer, the MAS layer is designed to model the behavior and decision-making of government, real estate developers, and residents. The CA layer and MAS layer are integrated upon the ULMG.

2.3.1. CA Layer. In the CA layer, the interactions between urban lakes and their surroundings could be reflected in the relationships between lake cells and their surrounding cells. In other words, a lake cell surrounded by land use cells is more active to transform than one surrounded by other lake cells. Such a state change of lake cells commonly happens at the edge of lakes. Therefore, the CA layer in DULAEM is different from traditional CA models.

(1) The Cell Space. As mentioned above, the second-level grid of ULMG consists of many square lattices that can be regarded as the cells of CA layer. Thus, the cell space of CA layer is obtained directly from the ULMG. In other words, the extent of the cell space is the same as the second-level 


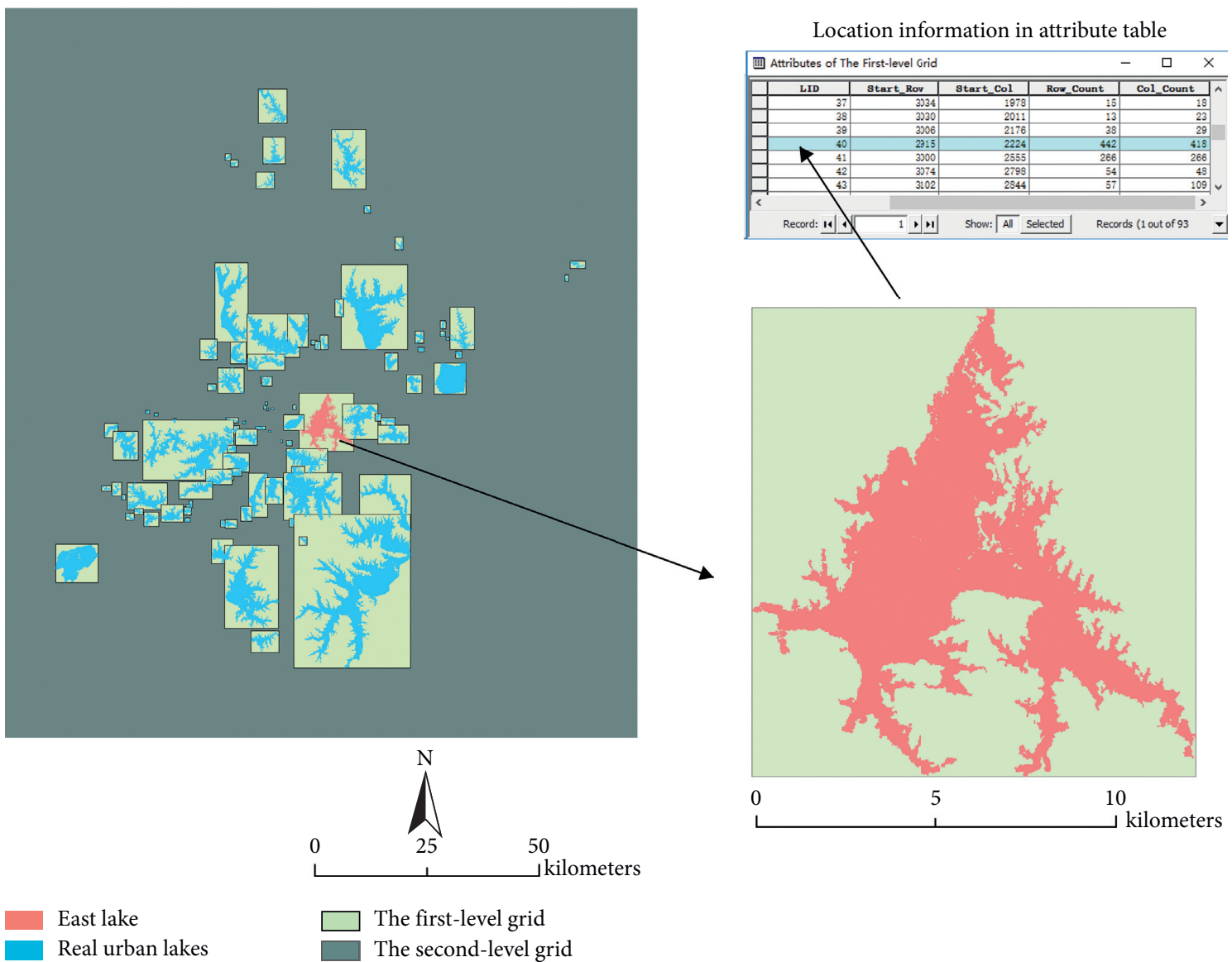

Figure 5: A case of ULMG for Wuhan.

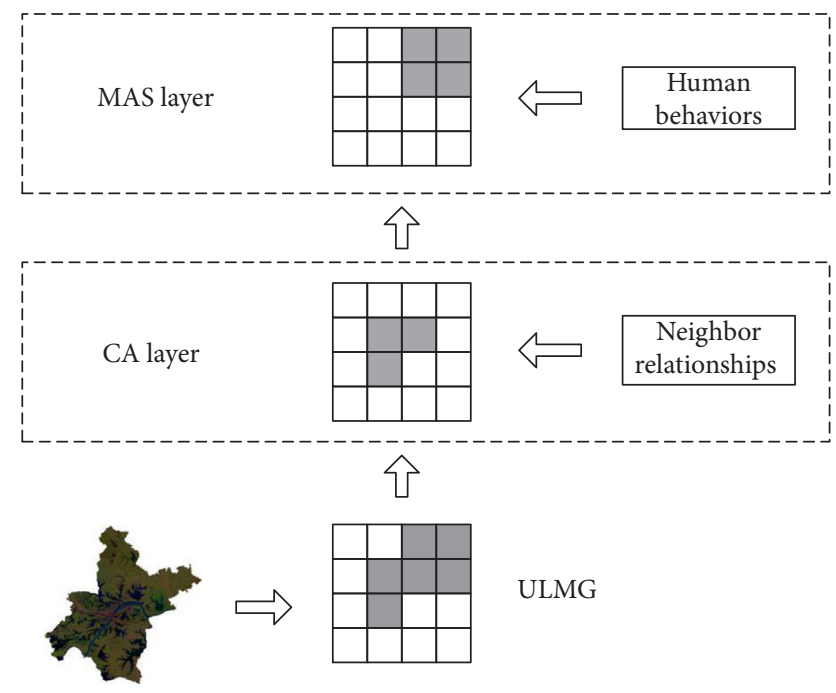

FIgURE 6: The structure of DULAEM. CA layer and MAS layer are integrated upon ULMG.

grid. The size of each cell is $30 \mathrm{~m} * 30 \mathrm{~m}$, which equals the size of a second-level grid and a pixel of Landsat images. In order to extract land use at the lakeside, there is a $100 \mathrm{~m}$ buffer around each lake. For this reason, the bounding rectangle of each buffer is designed as its new first-level grid according to the fundamentals of ULMG. The boundary of the cell space is the boundary of the new first-level grid. Thus, only those regions covered by the first-level grid are valid cell space.

(2) The Cell States. In the CA layer of DULAEM, the cells are divided into lake cells (LC) and land use cells (LUC). Their states are symbolized by $S_{\text {Lake }}$ and $S_{\text {land }}$, respectively.

As shown in Table $1, S_{\text {land }}$ includes five states that correspond to each of the land use categories. Thus, $S_{\text {land }}$ can be expressed by its land use type ID number as

$$
S_{\text {land }}=\{s \mid 1 \leq s \leq 5, \quad s \in Z\} .
$$

In order to distinguish it from land use cells, $S_{\text {Lake }}$ is expressed as a double-digit number as

$$
S_{\text {lake }}=10+N \text {, }
$$

where $N$ is the number of the contributing neighborhoods of the lake cell.

(3) The Neighborhood. In the CA layer of DULAEM, the neighborhood space is defined as the Moore neighborhood; namely, eight neighbor cells surround the center cell. Since a cell in the Moore neighborhood might be land use cell or lake cell and only the land use cells on neighborhood would contribute to the state change of lake cells, for a lake cell, its land use cell neighborhood is worked. If the number of these 
contributing neighborhoods is expressed as $N$, the value of $N$ is shown as follows:

$$
N=\{e \mid 0 \leq e \leq 8, \quad e \in Z\} .
$$

Figure 7 shows the values of $N$ in some cases. A lake cell, for example, is next to three lake cells and five land use cells in its Moore neighborhood. So, $N$ of the sample cells is five. Comparing different $N$ in Figure 7, variable $N$ can indicate how much a lake cell is affected by human activities. Specifically, the larger $N$ is, the more sensitive the lake cell is to human activities, and the more likely the cell state is to change. On the contrary, the smaller $N$ is, the less the impact of human activities on the land cell is, so the more stable the lake cell is. The cell state is not to change if a lake cell is surrounded by other lake cells completely. Therefore, the area change of urban lakes is reflected in the state changes of lake cells, which has at least one land use cell neighborhood.

(4) The Transition Rules. In the CA layer of DULAEM, each cell has an Activity to indicate how difficult its state is to change. In other words, Activity is the probability of state change. The domain of Activity is from 0 to 1 . The larger Activity is, the more likely the cell state is to change. The cell state will not change if Activity is zero.

(1) The transition rule of land use cells: the Activity of a land use cell is related to its cell state, neighborhood, and location.

(1) The cell state, namely, land use type in Table 1, will determine the initial value of Activity. For instance, the ecosystem of vegetation is relatively stable, and the land use cell with vegetation is unlikely to change. Agricultural land and developed land are both the major regions of human activities so that they have larger Activities [42]. Accordingly, the initial Activities of the land use cells $\left(I_{\text {land }}\right)$ are listed in Table 2 .

(2) The neighborhood: if a land use cell is surrounded by one of other land use types, it is likely to transform into that land use type.

(3) Location: urban development and human activities are the major factors of land use change. So the land use cells located in urban districts have larger Activities than the others located in the suburban districts.

Consequently, the Activities of land use cells could be expressed as

$$
\text { Activity }_{\text {land }}=I_{\text {land }} \times P \times L \text {, }
$$

where $I_{\text {land }}$ is the initial value of Activity which depends on the cell state; $P$ is the proportion of the most land use type in the neighborhood; $L$ is a parameter related to location and is called the urban location factor.

The urban location factor $(L)$ depends on four factors as shown in Figure 8: (a) natural factor, the distance from the Yangtze River and the Han River; (b) traffic factor,

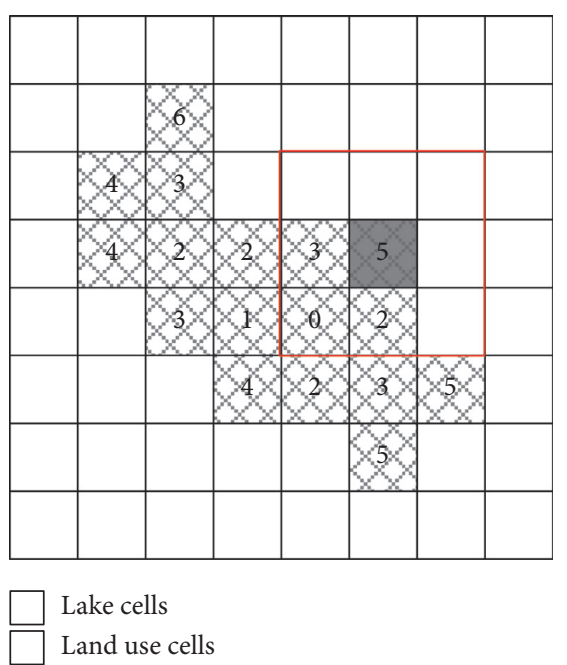

Figure 7: The number of the contributing neighborhoods $(N)$ for lake cells.

TABLE 2: The initial Activities of land use cells.

\begin{tabular}{lcc}
\hline ID & Cell state (land use type) & $I_{\text {land }}$ \\
\hline 1 & Water bodies & 0.01 \\
2 & Agricultural land & 0.5 \\
3 & Vegetation & 0.01 \\
4 & Developed land & 0.5 \\
5 & Bare land & 0.8 \\
\hline
\end{tabular}

the distance from main roads; (c) business factor, the distance from main commercial districts; and (d) residential factor, the distance from main residential areas. Therefore, $L$ is defined as

$$
L=\frac{1}{4} \sum_{i=1}^{4}\left(1-\frac{1}{1+e^{-\left(D_{i}-a / b\right)}}\right), \quad 1 \leq i \leq 4,
$$

where $D_{i}$ represents the above factors; $a$ and $b$ are parameters.

According to equation (5), an illustration of $L$ could be drawn as in Figure 8(e). In Figure 8, $L$ is shown as a raster map that has the same extent and grid size as the second-level grid of the ULMG. In the raster map, each pixel value is from 0 to 1 to indicate the degree of human activities.

The area change of urban lakes is nonlinear. In order to improve the indeterminacy of the CA layer, a random threshold condition is introduced to determine whether a land use cell is to change or not. In other words, if Activity is smaller than the random threshold, its state will be changed.

If a land use cell is to change, it enters the transition function to determine which land use type it will be. The transition function is based on roulette method. Its probabilities are distributed as in Table 3. 


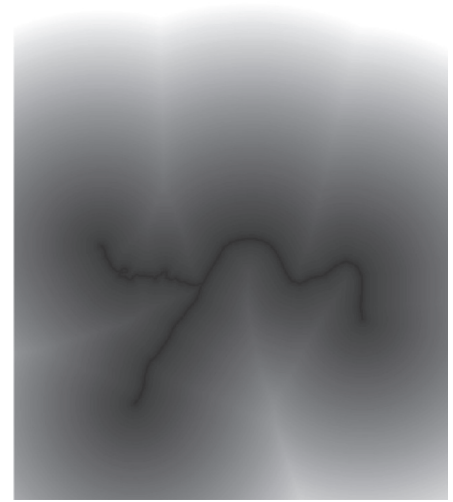

(a)

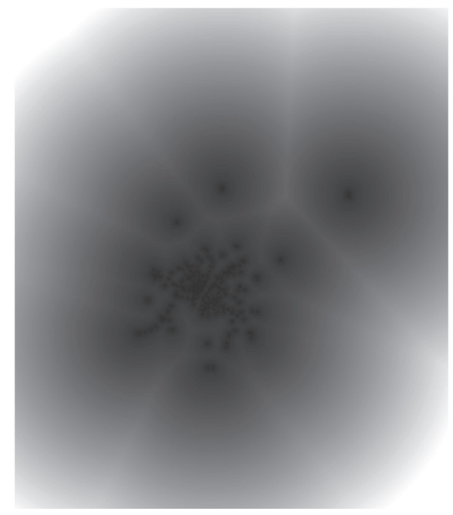

(c)

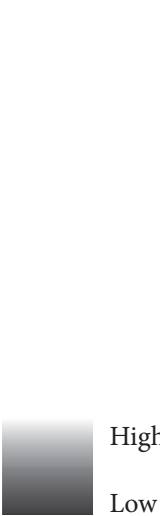

Low

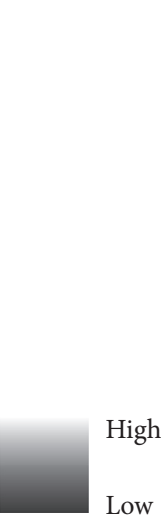

Low

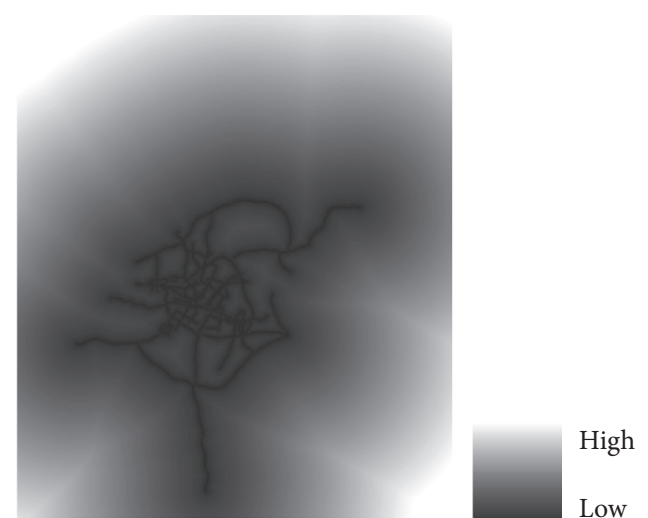

(b)

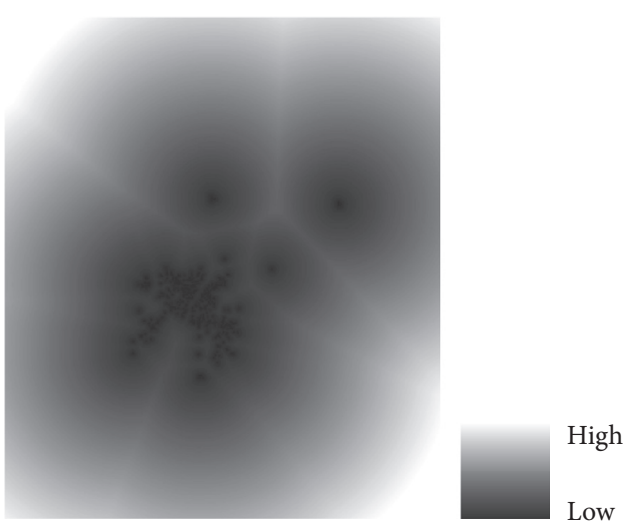

(d)

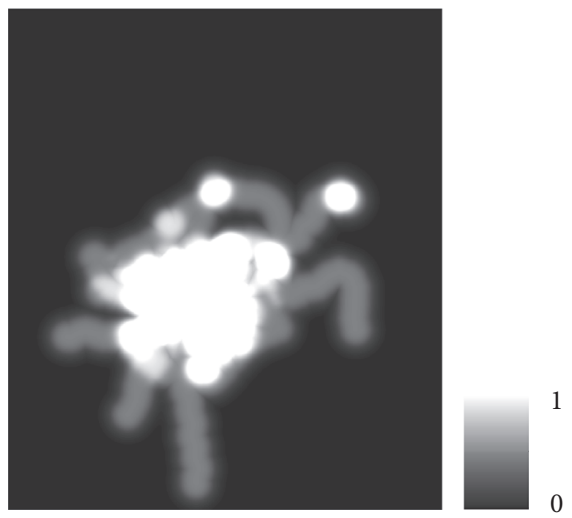

(e)

FIGURE 8: (a) Natural factor; (b) traffic factor; (c) business factor; (d) residential factor; (e) L.

TABLE 3: The transition function.

\begin{tabular}{lccc}
\hline Type & Description & Probability & Cumulative probability \\
\hline$P_{u}$ & The LUC will transform into developed land. & $P_{u}=L$ & $P_{u}$ \\
$P_{n}$ & The LUC will transform into the most land use type in its neighborhood. & $0.9\left(1-P_{u}\right)$ & $0.9+0.1 P_{u}$ \\
$P_{n r}$ & The LUC will transform into any of land use types in its neighborhood. & $0.05\left(1-P_{u}\right)$ & $0.95+0.05 P_{u}$ \\
$P_{r}$ & The LUC will transform into any of land use types. & $0.05\left(1-P_{u}\right)$ & 1 \\
\hline
\end{tabular}

In Table 3,

$$
P_{u}+P_{n}+P_{\mathrm{nr}}+P_{r}=1
$$

If the transition function is expressed as $T\left(P_{u}, P_{n}\right.$, $\left.P_{n r}, P_{r}\right)$, the transition rule of a land use cell can be summarized as 
$S_{\text {land }}^{t+1}=f\left(\operatorname{Activity}_{\text {land }}\left(S_{\text {land }}^{t}, P, L\right), T\left(P_{u}, P_{n}, P_{\mathrm{nr}}, P_{r}\right)\right)$,

where $S_{\text {land }}$ is the state of land use cell; $t$ is the number of iterations.

(2) The Transition Rule of Lake Cells

A lake cell's Activity depends on its cell state, neighborhood, and location.

(1) The Cell States

As we stated earlier, the number of the valid neighborhoods $(N)$ could indicate how much the lake cell is sensitive to urban development and human activities. The larger $N$ is, the more sensitive the cell is, and the larger Activity is. So, according to $N$, the sensitivities of lake cells are divided into four levels in this paper as in Table 4. As shown in Table $4, N$ being zero indicates that a lake cell is extremely stable because it is inside the lake. If $N$ is greater than five, that means more than half of the neighborhood is land use cells so that the lake cell is very sensitive to human activities and likely to change in the next period (Figure 9). In Figure 9, the lake cells at the sensitive level and the insensitive level represent that their sensitivities are greater than the cells at the stable level and smaller than the cells at the very sensitive level.

(2) The Neighborhoods

The neighborhood of a lake cell represents human activities in the lakeside. According to our previous studies, if land use in the lakeside is to change, especially change into agriculture land and developed land, the lake area might be decreased [42]. Therefore, a lake cell's Activity is not only related to the state of neighborhood but also should be concerned with the state change of neighborhood.

(3) Location

The same as land use cells, the lake cells located in the urban districts should be more active than the others in the suburban districts.

Therefore, a lake cell's Activity could be expressed as

Activity $_{\text {lake }}=I_{\text {lake }} \times\left(\alpha_{1} P_{c}+\alpha_{2} P_{a}+\alpha_{3} L\right), \quad 0 \leq \alpha_{1}, \alpha_{2}, \alpha_{3} \leq 1$,

where $I_{\text {lake }}$ is the initial value of Activity which depends on $N$; $P_{c}$ is the proportion of the valid neighborhoods that have changed their states in this period; $P_{a}$ is the proportion of agricultural land in the neighborhood; $L$ is the urban location factor defined as in equation (5); $\alpha_{1}, \alpha_{2}$, and $\alpha_{3}$ are undetermined coefficient, and $\alpha_{1}+\alpha_{2}+\alpha_{3}=1$.

In equation (8), if a lake cell is located in the urban districts, $L$ plays a leading role in the lake cell's Activity. In the suburban districts, agricultural land is increasing and $L$ is decreasing so that $P_{a}$ becomes the leading factor of a lake cell's Activity. Hence, equation (8) represents the lake cell's Activity reasonably in both the urban and suburban districts.

If a lake cell's Activity is smaller than a random threshold value, it enters the program of transition function $T\left(P_{u}, P_{n}\right.$, $\left.P_{n r}, P_{r}\right)$ to determine which land use type it will be in the next period.

Therefore, the transition rule of lake cells could be summarized as

$$
S_{\text {lake }}^{t+1}=f\left(\operatorname{Activity}_{\text {lake }}\left(S_{\text {land }}^{t}, S_{\text {land }}^{t+1}, N, L\right), T\left(P_{u}, P_{n}, P_{n r}, P_{r}\right)\right),
$$

where $t$ is the number of iterations.

As in equations (7) and (9), whether the cell state is to change or not depends on its Activity. The transition function $T\left(P_{u}, P_{n}, P_{n r}, P_{r}\right)$ determines which land use type the lake cells or land use cells will be. As in equation (9), $S_{\text {land }}^{t+1}$ is a necessary transition condition for $S_{\text {lake }}^{t+1}$. Therefore, there are two phases in a transition period as in Figure 10.

2.3.2. MAS Layer. Although there is the urban location factor $(L)$ in equations (4) and (8), the CA layer still cannot totally represent human activities. For this reason, a MAS layer was introduced in DULAEM upon the CA layer.

There are three typical agents concerned with the area change of urban lakes: the government, the real estate developer, and the resident.

(1) The Government Agent. The government plays a leading role in the development and utilization of urban lakes. It aims to give consideration to both urban economic development and ecological protection. Generally, land value is higher in the lakeside so that human activities and LUCC are more frequent here. In order to isolate lakes from human activities, the government usually plans a greenbelt and wetland around the lakes. For instance, in Wuhan, East Lake is the largest lake in the urban districts. So there are many human activities around East Lake such as real estate development and aquaculture industry. On the other hand, the government attaches great importance to the ecological protection of East Lake through strict planning and supervision.

Therefore, in the MAS layer, the behavior of the government agent is summarized as that the strength of governmental supervision for lakes and lands gradually decreases with distance from the center of city [43]. The impact of the government agent on Activity is shown as

$$
\text { Activity }=\text { Activity } * \mathrm{IF}_{\text {gov }},
$$

where $\mathrm{IF}_{\text {gov }}$ is the impact factor of the government agent and it is from 0 to $1 . \mathrm{IF}_{\text {gov }}$ is zero in the center of city and gradually increases to 1 with distance from the center of city.

(2) The Real Estate Developer Agent. The development of real estate is one of the primary causes for lake shrinkage, because filling in lakes can increase the land available to build houses so that the developers can achieve more economic 
Table 4: The initial Activities of lake cells.

\begin{tabular}{lcc}
\hline $\mathbf{N}$ & Sensitivity & $I_{\text {lake }}$ \\
\hline$N=0$ & Stable & 0 \\
$1 \leq N \leq 2$ & Insensitive & 0.01 \\
$3 \leq N \leq 4$ & Sensitive & 0.1 \\
$N \geq 5$ & Very sensitive & 0.2 \\
\hline
\end{tabular}

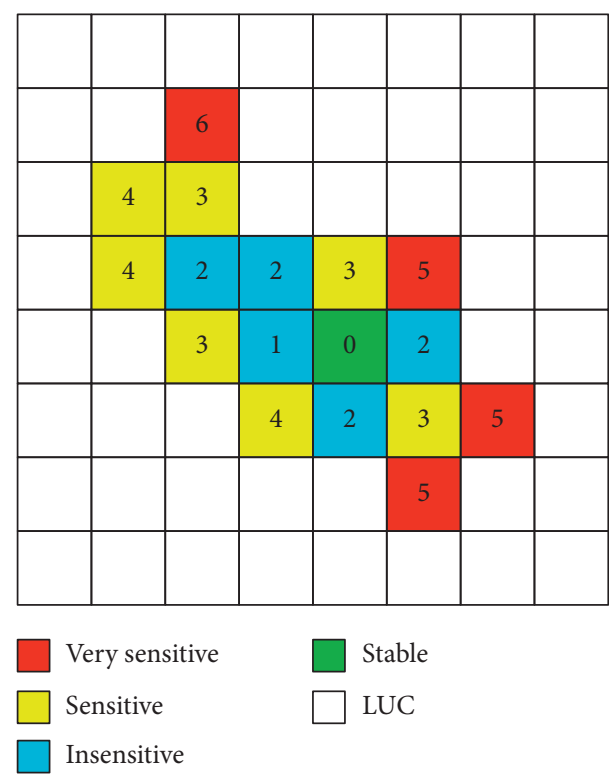

FIGURE 9: The sensitivity of lake cells.

benefits. However, filling in lakes is bound by the cost and earning of developers. As shown in Figure 11, in the urban districts, the price of houses is high, but filling in lakes is almost impossible because the governmental supervision is strong here. In the districts away from the city center, the developers might fill in lakes more easily than in the urban districts, but it is not cost-effective for them because of lower house prices. Therefore, filling in lakes by the real estate developer agent usually occurs in the junction zone between the urban and suburban districts. South Lake of Wuhan, for example, was surrounded by agriculture land in the early 1990s. As the city expanded constantly, South Lake was almost surrounded by developed land by 2002. In the meantime, the area of South Lake reduced by $48.4 \%$, and the reduced region had been nearly transformed into residential or commercial land.

Therefore, the impact of the real estate developer agent on Activity is expressed as in the following equation:

$$
\text { Activity }=\text { Activity } * \mathrm{IF}_{\text {deve }} \text {, }
$$

where $\mathrm{IF}_{\text {deve }}$ is the impact factor of the real estate developer agent and it is greater than 1 . The more close $\mathrm{IF}_{\text {deve }}$ is to the junction zone, the greater it is.

(3) The Resident Agent. In some cases, the lake area had been occupied by the individual behaviors of residents, such as farming and fish-farming. These individual behaviors generally happen away from the city center because of the government and the real estate developers. Many lakes in the suburban districts, such as Wu Lake and Qingling Lake, had changed into ponds or paddy fields.

Therefore, the impact of the resident agent could be shown on the Activity as

$$
\text { Activity }=\text { Activity } * \mathrm{IF}_{\text {resi }} \text {, }
$$

where $\mathrm{IF}_{\text {resi }}$ is the impact factor of the resident agent and it is greater than $1 . \mathrm{IF}_{\text {resi }}$ is close to 1 in the urban districts and is increasing in the suburban districts.

(4) Interactions Between Each Agent. As shown in Table 5, the government agent has the highest priority level and strength so that developers and residents must be subjected to governmental regulations. The resident agent has the lowest priority and the weakest strength, because the behaviors and decision-makings of residents should be more random than the developers'.

The priority levels of the agents determine the spatial distributions of their impact factors. The government agent has the highest priority level and supervises lakes mainly in the urban districts. So the developer agent develops real estate only in the junction zone between the urban and suburban districts because of governmental supervisions. The impact of the resident agent is mainly reflected in the suburban districts, because its priority level is the lowest.

(5) The Urban Border and Impact Factors. As mentioned above, it is necessary to determine the junction zone between urban and suburban districts. Accordingly, we proposed a border called the urban border. The urban border is a kind of geographic boundary rather than an administrative boundary. It can represent the actual situation of urban expansion. The urban border divides the city into the urban land-based regions and the agricultural land-based regions. So, extracting urban land and agricultural land from remote sensing images is the most direct approach to determine the urban border.

In this paper, the urban border is acquired by the urban location factor $(L)$. According to Figure 8(e), a series of isolines could be generated as in Figure 12(a). Then the Landsat image of Wuhan in 2002 is overlapped with these isolines. As shown in Figure 12(b), urban land in the Landsat image is nearly within the isoline $L=0.7$. Therefore, in the MAS layer, the urban border is defined as follows:

$$
B=\left.L\right|_{L=0.7}
$$

where $L$ is the urban location factor. 


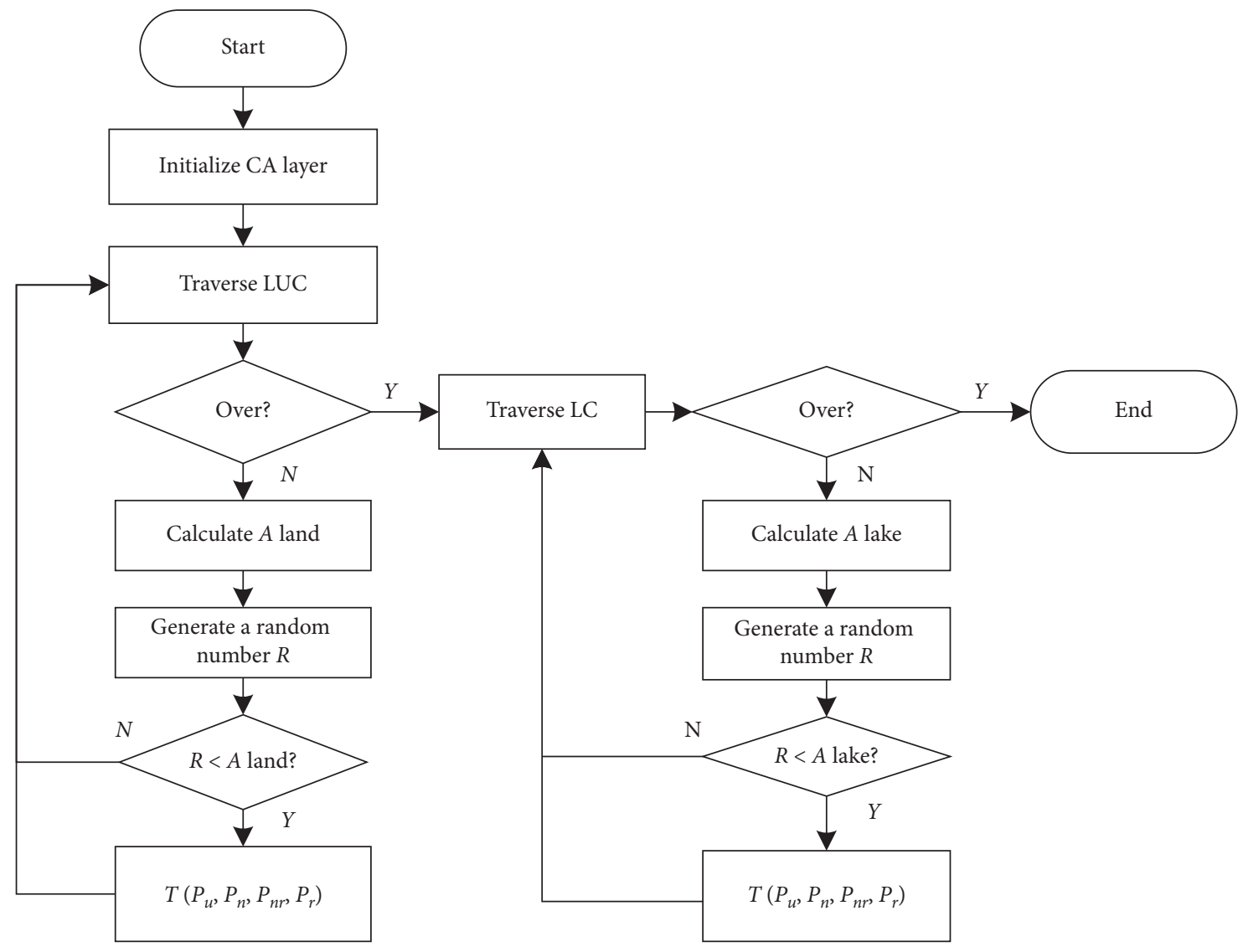

Figure 10: The flow diagram of CA layer.

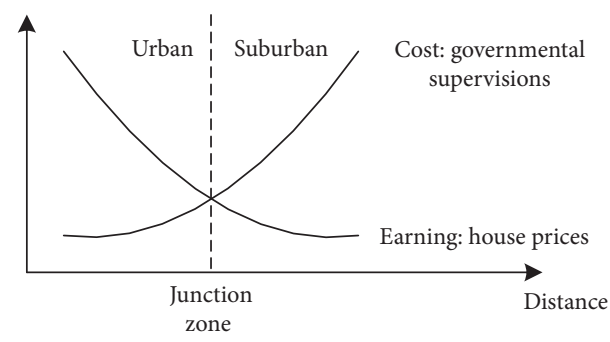

FIgURE 11: Filling in lakes by the real estate developer agent tends to gather around the junction zone because of house prices and governmental supervisions.

On the basis of the urban border, the impact factors of three agents are simplified as in Figure 13, where $B$ is the urban border and $L$ is the urban location factor.

2.3.3. Integration of CA Layer and MAS Layer. In the CA layer of DULAEM, the transition rules of land use cells and lake cells depend on their Activities as shown in equations (4) and (8). On this basis, in the MAS layer, the impact factors in Figure 13 are added to Activities of land use cells and lake cells as in the following two equations, respectively:

$$
\begin{aligned}
& \text { Activity land }_{\text {land }} \times P \times L \times \mathrm{IF}_{\text {gov }} \times \mathrm{IF}_{\text {deve }} \times \mathrm{IF}_{\text {resi }}, \\
& \text { Activity lake } \\
& \text { lake }
\end{aligned}
$$

where Activity land and Activity lake are the Activities of land use cells and lake cells, respectively; $I_{\text {land }}$ is the initial Activity of land use cells, which depends on its cell state; $I_{\text {lake }}$ is the initial Activity of lake cells, which depends on $N$; $P$ is the proportion of the most land use types in the neighborhood; $P_{c}$ is the proportion of the valid neighborhoods that have changed their states in this period; $P_{a}$ is the proportion of agricultural land in the neighborhood; $L$ is the urban location factor defined as in equation (5); $\alpha_{1}$, $\alpha_{2}$, and $\alpha_{3}$ are undetermined coefficients, and $\alpha_{1}+\alpha_{2}+\alpha_{3}=1 ; \mathrm{IF}_{\text {gov }}, \mathrm{IF}_{\text {deve, }}$ and $\mathrm{IF}_{\text {resi }}$ are the impact factors.

Meanwhile, the CA layer and MAS layer are integrated on the ULMG. The first-level grid of the ULMG could limit the extents and borders of the cell space and the agent space. The second-level grid is a carrier of cells and agents. In other words, a grid in the second level is a cell in the CA layer, an agent unit in the MAS layer, and a pixel in the remote sensing images. 
TABLE 5: Relationships between the government agent, the developer agent, and the resident agent.

\begin{tabular}{lcc}
\hline Agent & Behaviors and decision-makings & Priority level \\
Government agent & Balance economy and ecology; supervise major lakes. & High \\
Real estate developer agent & Go after economic benefit; filling in lakes to build. \\
Resident agent & Seek personal interests; reclaim land from lakes. & Low \\
\hline
\end{tabular}

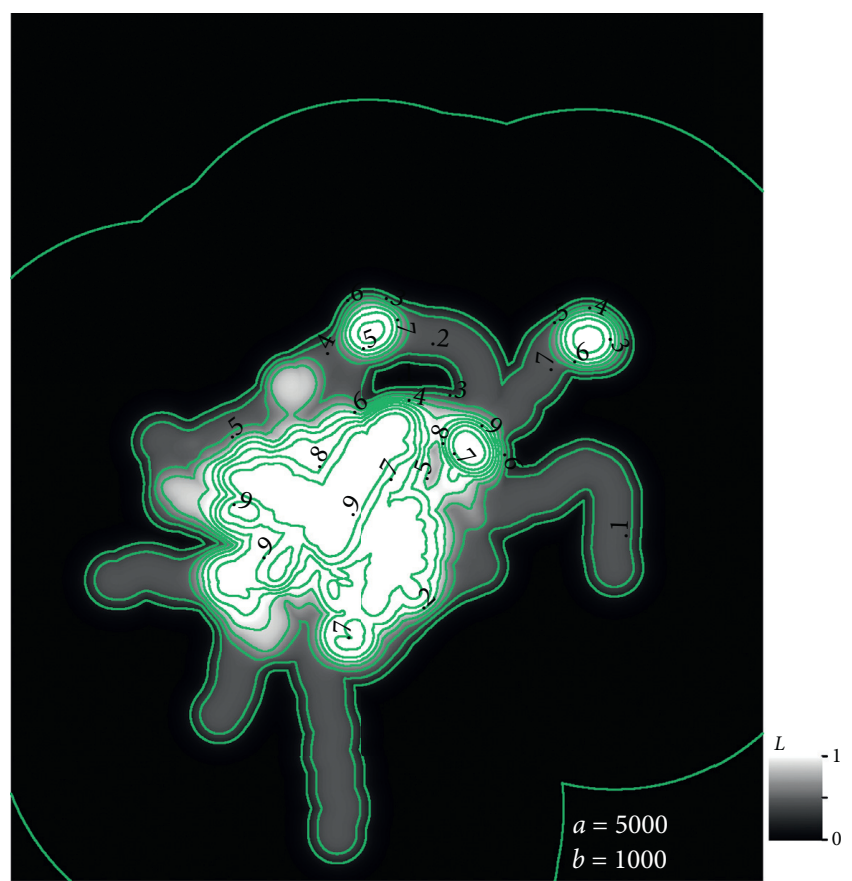

- Isoline

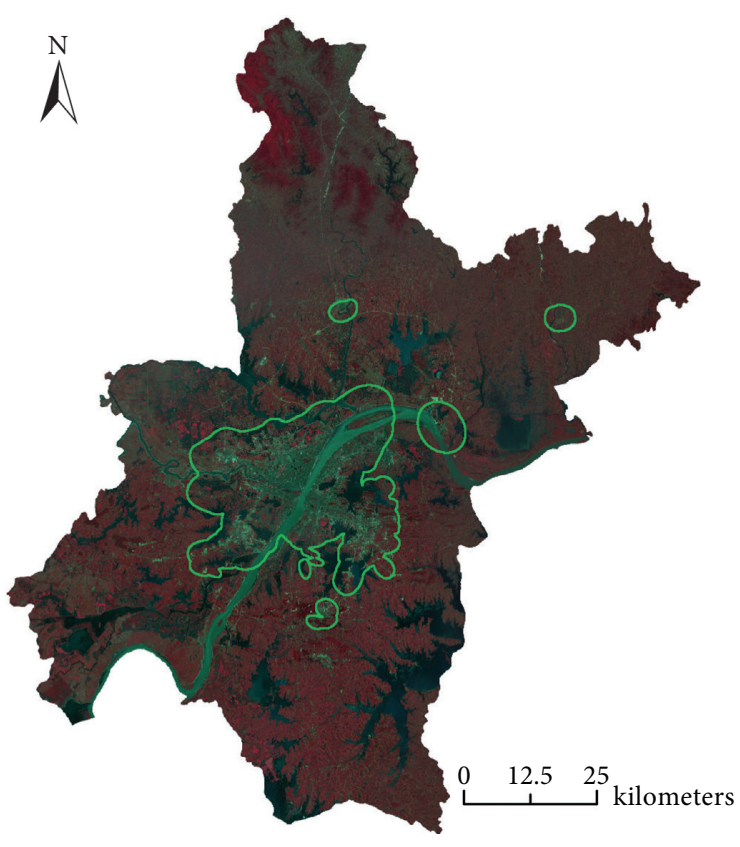

$L=0.7$

(a)

(b)

Figure 12: (a) A series of isolines from $L$. (b) The urban border is the isoline $L=0.7$.

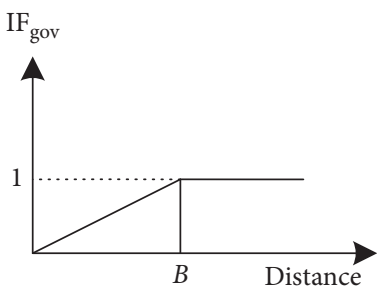

(a)

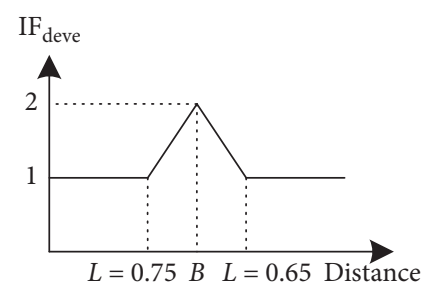

(b)

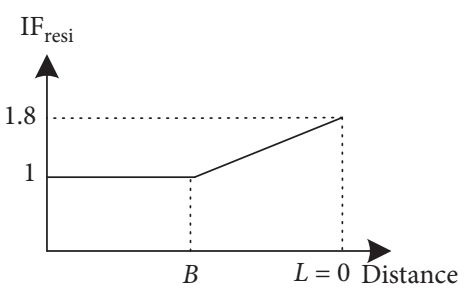

(c)

FIgURE 13: The impact factors of three agents.

2.3.4. Evaluation of DULAEM. In this paper, the accuracy of DULAEM is evaluated by the global relative error (GRE) defined as

$$
\mathrm{GRE}_{k}=\frac{\sum_{i=1}^{N}\left|A_{i k}-A_{i}\right| / A_{i}}{N},
$$


TABLE 6: Sixteen typical cases of $\alpha_{1}, \alpha_{2}$, and $\alpha_{3}$.

\begin{tabular}{lccc}
\hline SN & $\alpha_{1}$ & $\alpha_{2}$ & $\alpha_{3}$ \\
\hline A & 1 & 0 & 0 \\
B & 0 & 1 & 0 \\
C & 0 & 0 & 1 \\
D & 0.75 & 0.25 & 0 \\
E & 0.75 & 0 & 0.25 \\
F & 0.25 & 0.75 & 0 \\
G & 0 & 0.75 & 0.25 \\
H & 0.25 & 0 & 0.75 \\
I & 0 & 0.25 & 0.75 \\
J & 0.5 & 0.5 & 0 \\
K & 0.5 & 0.25 & 0.25 \\
L & 0.5 & 0 & 0.5 \\
M & 0.25 & 0.5 & 0.25 \\
N & 0.25 & 0.25 & 0.5 \\
O & 0 & 0.5 & 0.5 \\
P & 0.33 & 0.34 & 0.33 \\
\hline
\end{tabular}

TABLe 7: The statistics of GRE.

\begin{tabular}{lccc}
\hline SN & & GRE (based on CA layer) \\
& Mean & Variance & Optimum \\
\hline A & 0.830770 & $1.03794 E-05$ & 0.818641 \\
B & 0.636786 & $2.51504 E-05$ & 0.623489 \\
C & 0.584356 & $1.08307 E-05$ & 0.57522 \\
D & 0.589527 & $3.44083 E-05$ & 0.57453 \\
E & 0.455851 & $2.41454 E-05$ & 0.443834 \\
F & 0.631433 & $2.89263 E-05$ & 0.619088 \\
G & 0.431735 & $6.38359 E-05$ & 0.411336 \\
H & 0.560628 & $1.09643 E-05$ & 0.553631 \\
I & 0.482183 & $2.12147 E-05$ & 0.47353 \\
J & 0.615415 & $2.18722 E-05$ & 0.605141 \\
K & 0.403027 & $5.38433 E-05$ & 0.38217 \\
L & 0.523602 & $2.17607 E-05$ & 0.512491 \\
M & 0.40852 & $6.9555 E-05$ & 0.388086 \\
N & 0.438803 & $2.25085 E-05$ & 0.424297 \\
O & 0.409725 & $4.97009 E-05$ & 0.39318 \\
P & 0.405606 & $4.13266 E-05$ & 0.38758 \\
\hline
\end{tabular}
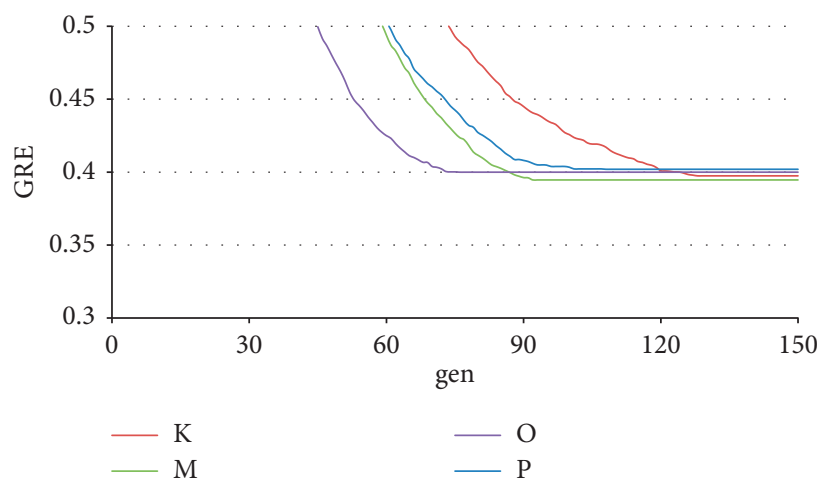

FIgure 14: The iterations of Groups K, M, O, and P. 
K

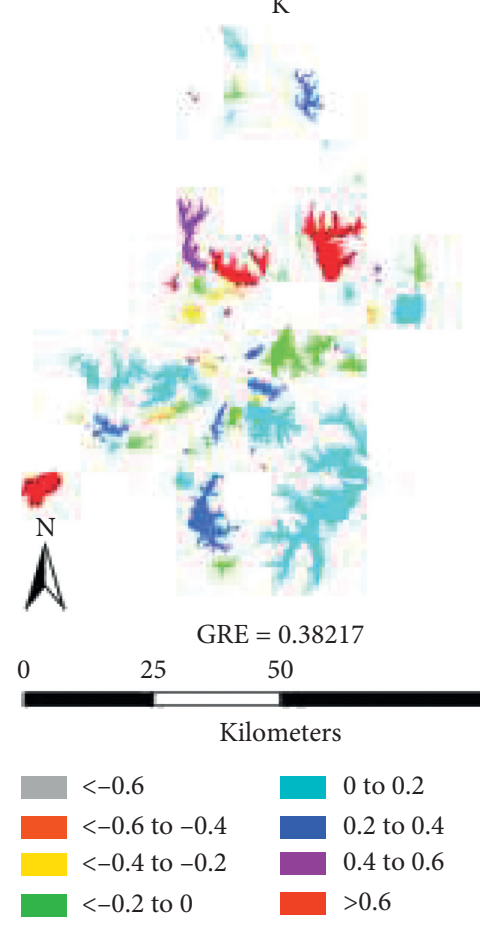

(a)

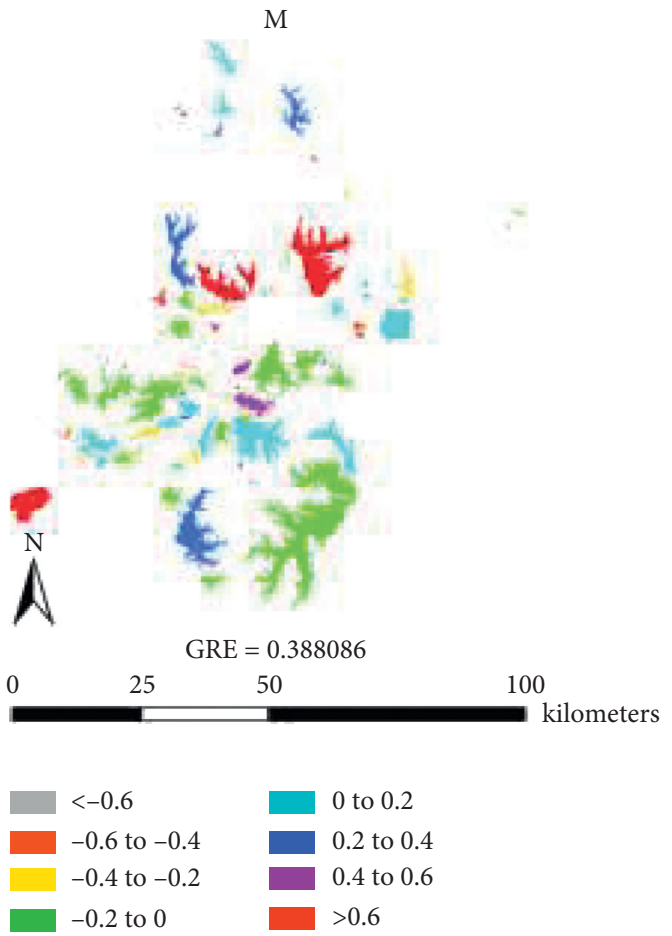

(b)

$\mathrm{P}$
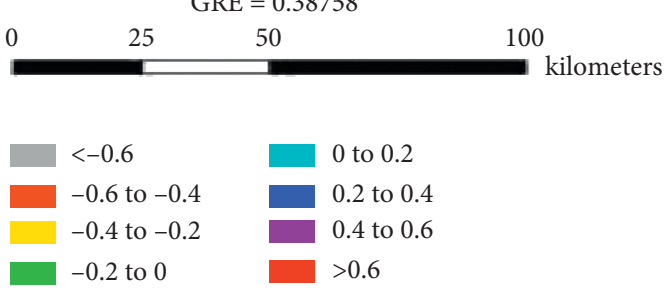

(c)

FIgUre 15: The spatial distribution of LRE of Groups (a) K, (b) M, and (c) P.

where $A_{i k}$ is the area of the $\mathrm{i}^{\text {th }}$ lake in the $k^{\text {th }}$ period; $A_{i}$ is the actual area of the $i^{\text {th }}$ lake in 2002; $N$ is the number of lakes; and $\left(A_{i k}-A_{i}\right) / A_{i}$ is the local relative error (LRE) of the $i^{\text {th }}$ lake in the $k^{\text {th }}$ period.

\section{Results and Discussions}

3.1. Evolutions Based on CA Layer. In equations (8) and (15), there are still three undetermined coefficients: $\alpha_{1}, \alpha_{2}$, and $\alpha_{3}$. 


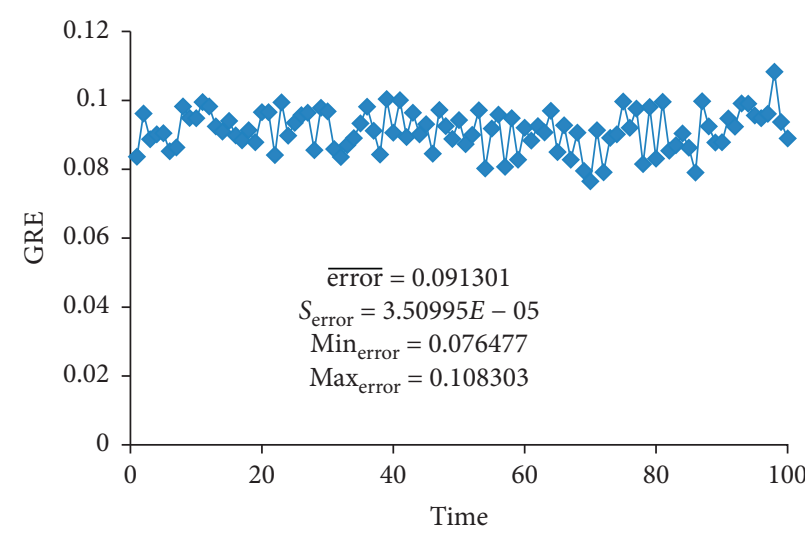

(a)

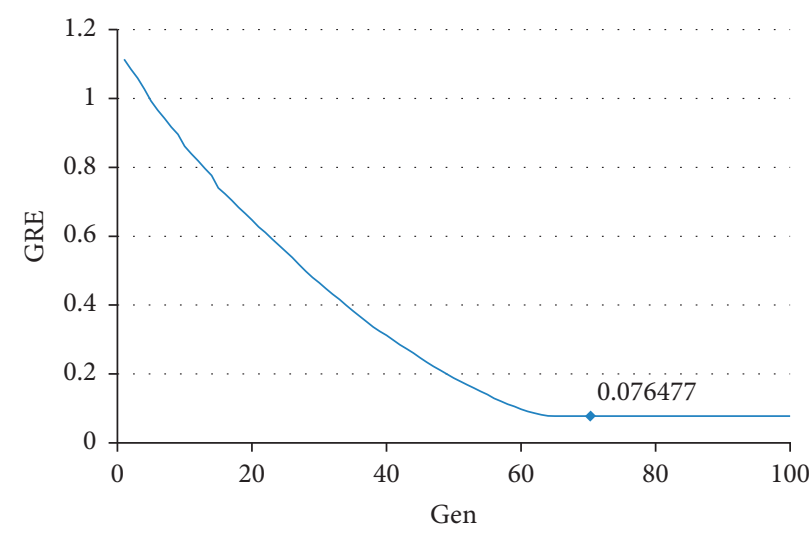

(b)

FIgURE 16: (a) The statistics of GREs in 100 simulations. (b) The iterations of DULAEM.

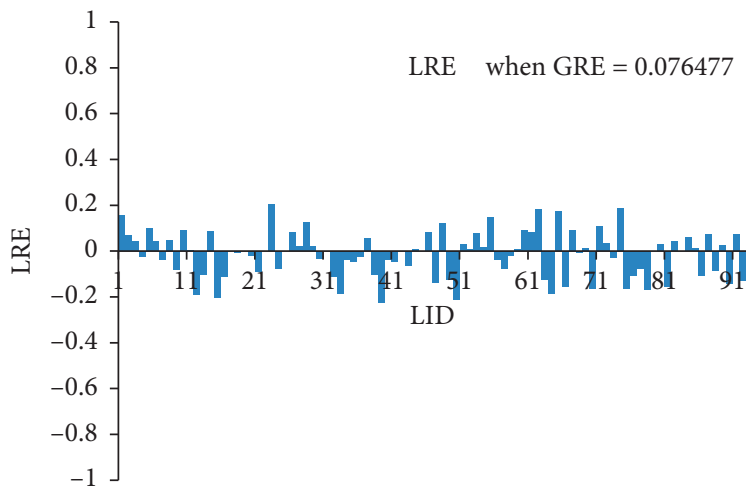

(a)

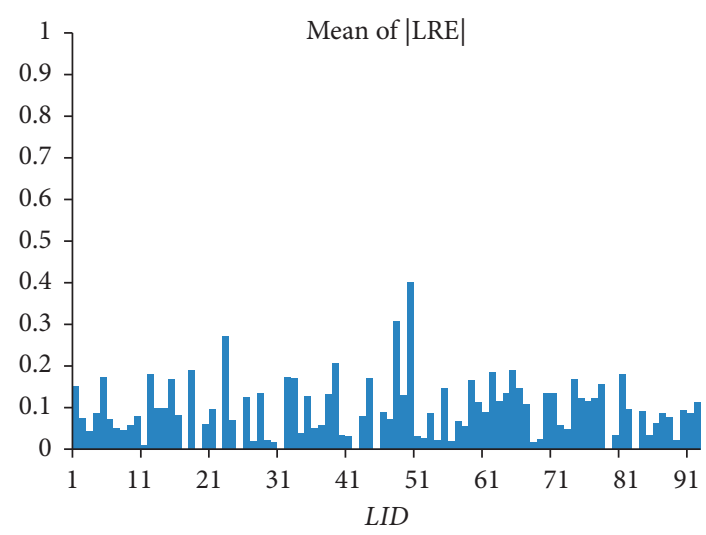

(c)

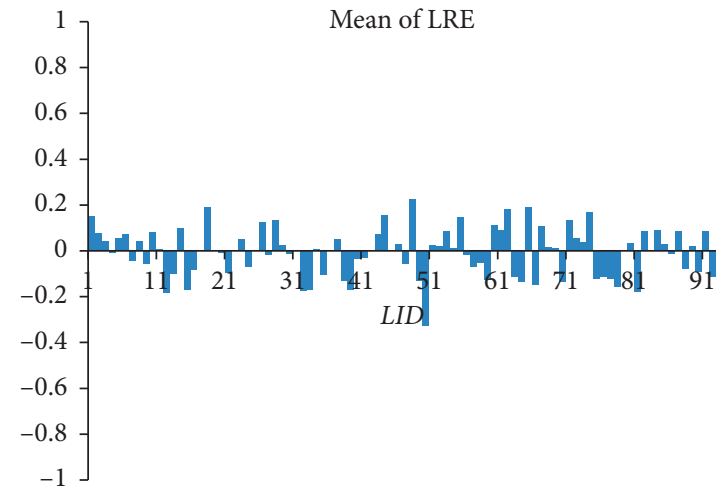

(b)

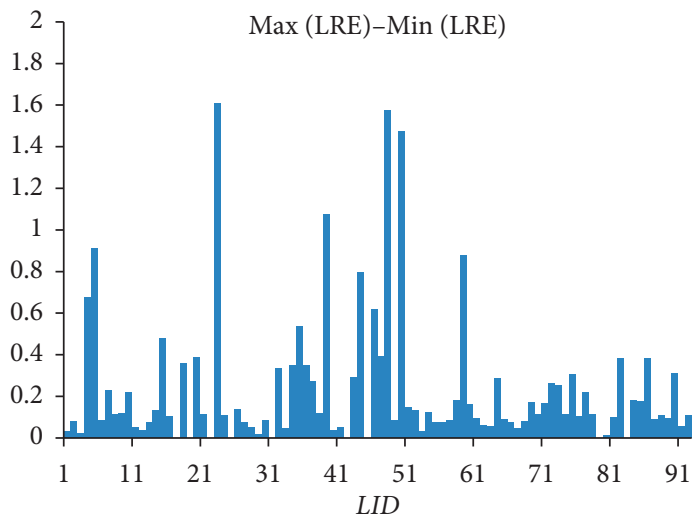

(d)

FIgURE 17: (a) LRE of each lake. (b) The mean LRE of each lake. (c) The mean of the absolute value of LRE of each lake. (d) The difference between maximum and minimum of LRE of each lake.

In order to determine these coefficients and assess their effect on the GRE, we tested 16 groups of typical cases (as Table 6). For each group of $\alpha_{1}, \alpha_{2}$, and $\alpha_{3}$, we ran DULAEM without the MAS layer 100 times and calculated the GREs according to equation (16).

The mean, variance, and optimum of GREs in 100 simulations on each group are shown in Table 7 . The statistical results indicate that the GREs in Groups K, $\mathrm{M}, \mathrm{O}$, and $\mathrm{P}$ are less than those in the other groups. Their mean values are all close to 0.40 . Their optimums are all less than 0.40 , and $K<P<M<O$.

Figure 14 shows the iterations of Groups $\mathrm{K}, \mathrm{M}, \mathrm{O}$, and $\mathrm{P}$ by the CA layer. As shown, the fastest group is Group O, which can reach steady value before the $80^{\text {th }}$ generation. 


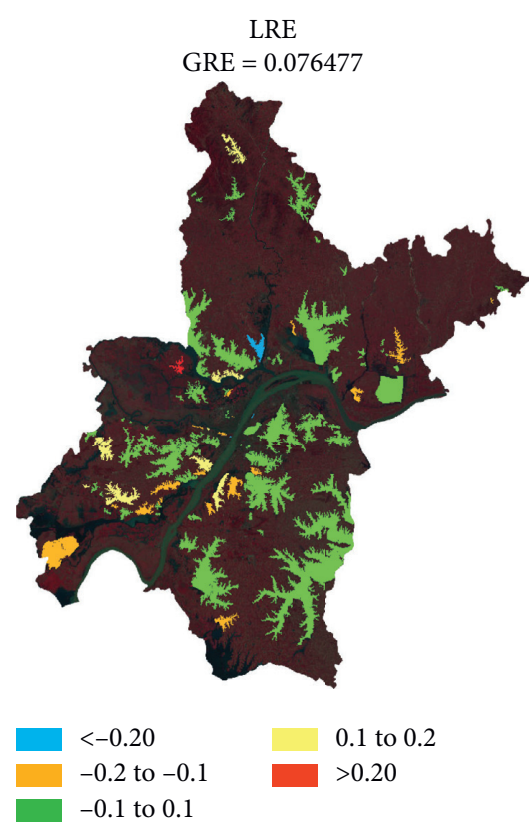

(a)

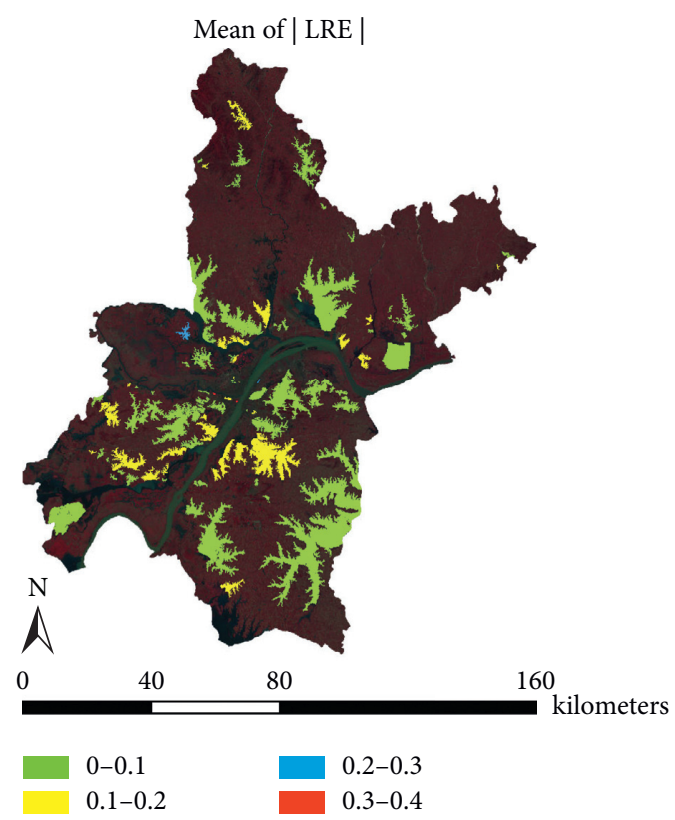

(b)

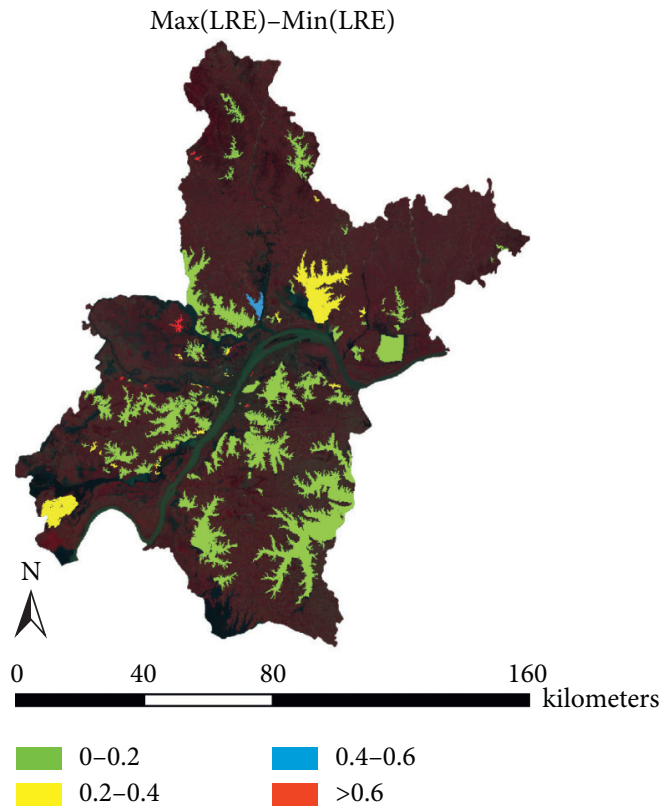

(c)

FIGURE 18: The spatial distributions of (a) LRE, (b) the mean of the absolute values of LRE, and (c) the difference between maximum and minimum of LRE.

Group $M$ and Group $P$ reach steady state around $90^{\text {th }}$ generation and $110^{\text {th }}$ generation, respectively. Group $\mathrm{K}$ needs at least 130 iterations to reach steady state.

According to Group $\mathrm{O}$, farm works whose coefficient is $\alpha_{2}$ and the urban location factor whose coefficient is $\alpha_{3}$ are the primary cause of the evolution of urban lakes. If $\alpha_{2}$ equals $\alpha_{3}$, the GREs are less (see Groups K, O, and P). On the basis of $\alpha_{2}$ and $\alpha_{3}$, an appropriate $\alpha_{1}$ could reduce the GREs further (see Groups $\mathrm{K}$ and $\mathrm{P}$ ). In addition, the number of iterations to reach steady value depends on $\alpha_{2}$ and $\alpha_{2}$. The greater $\alpha_{1}$ is and the smaller $\alpha_{2}$ is, the more iterations are needed.
Figure 15 shows the spatial distributions of LREs under the best GRE of Groups K, M, and P. As shown, three distributions are similar: the lakes located in the urban districts are almost overfitted; namely, their LREs are less than zero; and the lakes located in the suburban districts are almost underfitted; namely, their LREs are greater than zero. Some suburban lakes in Figure 15(b) are also overfitted because $\alpha_{2}$ in Group $M$ is greater than that in Groups $\mathrm{K}$ and $\mathrm{P}$.

Meanwhile, it is necessary to improve model by MAS layer. 

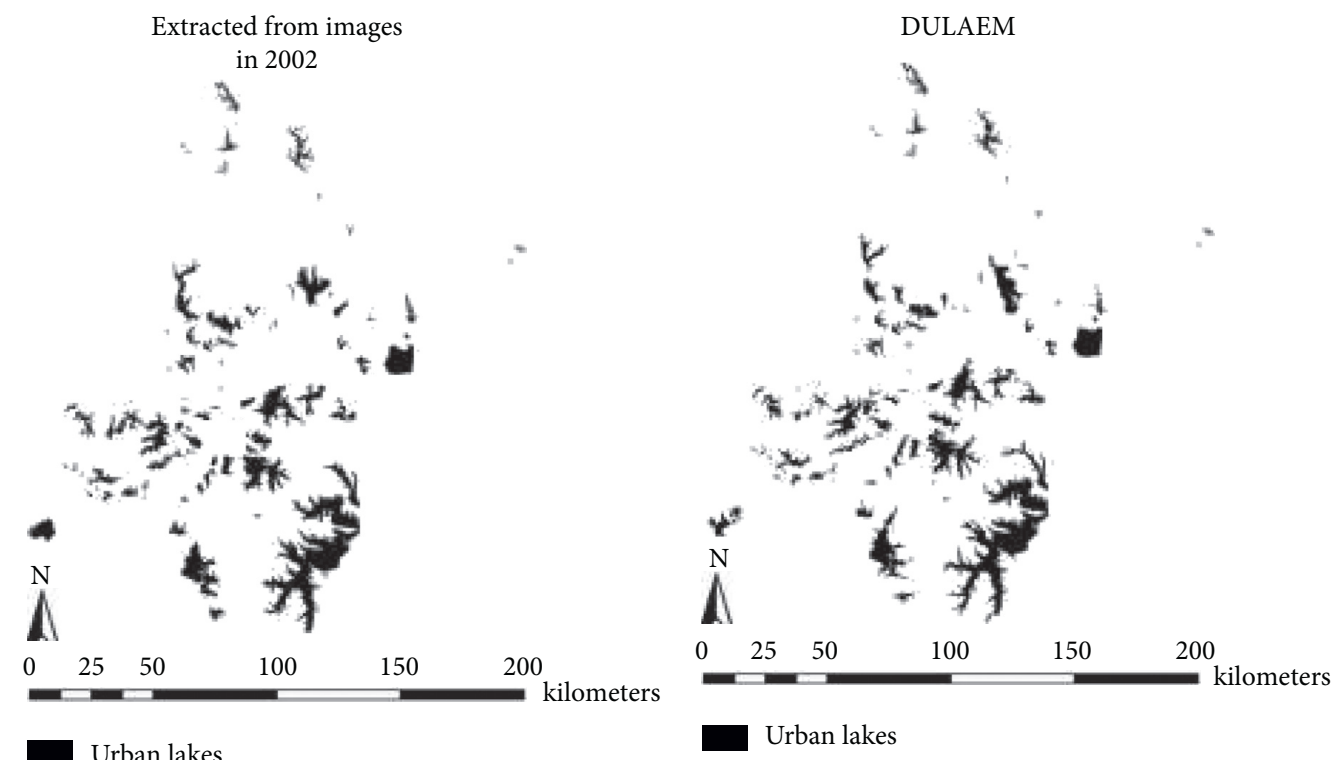

(a)

(b)

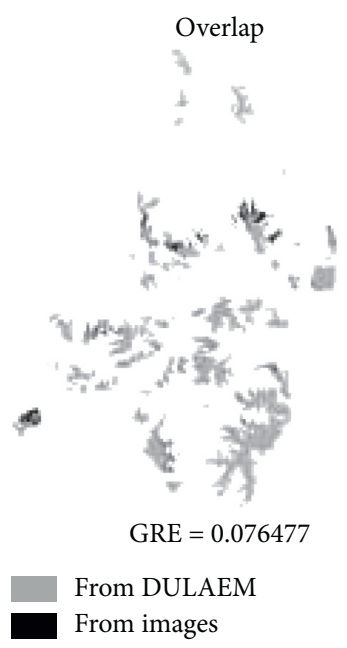

(c)

FIGURE 19: (a) Urban lakes extracted from Landsat images in 2002. (b) Urban lakes evolved by DULAEM. (c) Overlap of urban lakes in (a) with those in (b).

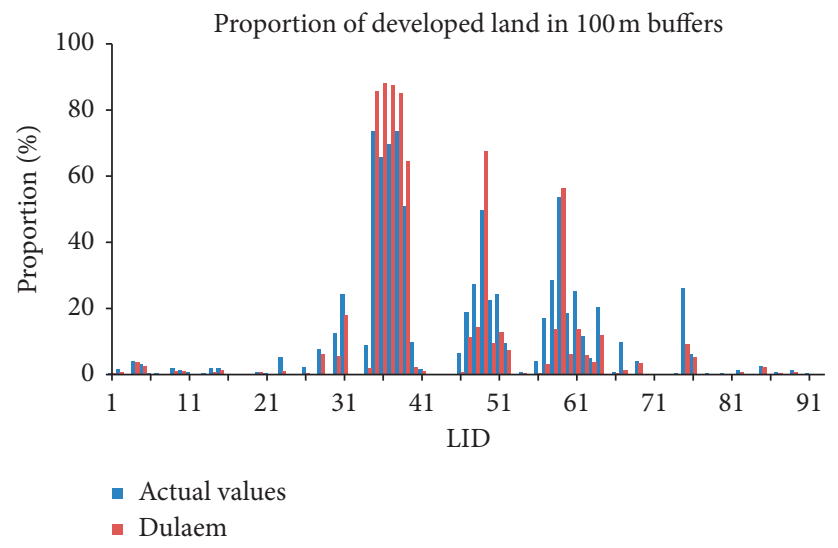

FIGURE 20: The proportion of developed land in $100 \mathrm{~m}$ lakeside buffers. 
3.2. Evolutions Based on DULAEM. By comparing above GREs and iterations, we adopted Group $\mathrm{P}\left(\alpha_{1}=0.33\right.$, $\alpha_{2}=0.34$, and $\left.\alpha_{3}=0.33\right)$ in the CA layer and introduced MAS layer to run DULAEM 100 times.

3.2.1. Evolutions of Lake Area. GREs and LREs in 100 simulations were calculated according to (16).

Figure 16(a) shows the statistical result of GREs. A contrast between Figure 16(a) and Table 7 indicates that DULAEM could improve the GRE more than a pure CA layer. The mean of GRE is less than $10 \%$, up to 0.091301 . The optimum of GRE is 0.076477 . At the same time, DULAEM is faster due to MAS layer so that it reaches steady value before the $70^{\text {th }}$ generation (Figure 16(b)).

However, according to Figure 17, although the GRE can be kept below $10 \%$, there are a few lakes with larger error in some cases. For instance, as shown in Figure 17(b), the minimum of the mean of LRE is less than $20 \%$. In Figure $17(d)$, the LRE could be fluctuant sharply so that the difference between maximum and minimum is even more than $150 \%$.

Figure 18 shows the spatial distribution of LREs. The lakes with larger LRE tend to gather in the suburban districts irregularly. They were all small lakes in 1991 and had larger loss rate during 1991 and 2002. Thus, the lake area change in the suburban districts is more random and complex than that in the urban districts.

An overlap analysis in Figure 19 shows that the simulation result by DULAEM well matched with the real lake areas extracted by Landsat images. However, if a lake had been filled in over $50 \%$, there could be a big error between the real lake area and the simulation result.

3.2.2. Evolutions of LUCC. The evolution of LUCC is hard to be assessed by traditional methods such as the Kappa coefficient, because there is only a $100 \mathrm{~m}$ buffer at the lakeside. For this reason, the proportion of each land use type in the buffer of each lake is contrasted with its real values extracted from Landsat images. For instance, the proportions of developed land evolved by DULAEM have similar tendency to the real values in Figure 20. Particularly, in the buffers where the proportion of developed land is greater than $40 \%$ in reality, the simulation result is larger than the real value. On the other hand, the simulation result is smaller than the real value in the suburban buffers. The polarization like in Figure 20 could be caused by the transition function $T\left(P_{u}, P_{n}, P_{n r}, P_{r}\right)$ in the CA layer.

\section{Conclusions}

This paper proposed a dynamic model based on a special geographic information grid (ULMG) and MAS-CA model. A case study on Wuhan, China, proved that the model is effective for urban lake area evolutions.

The ULMG is a two-level grid that has the advantages of both vector model and raster model. It is designed for running MAS-CA model originally. The structure of ULMG is efficient for massive amounts of grids. It is available for the data management of large-scale, discrete spatial features such as urban lakes.

The CA layer of DULAEM indicates that urban lake area changes have correlations with their activities, which depends on locations and surrounding environments. For the lakes in the center of city, broad greenbelt landscape of at least 30 meters is necessary.

The MAS layer of DULAEM indicates that the area changes of urban lakes are also related to governments, real estate developers, and residents. These three agents have different actions in extent, strength, and priority. The government must pay more attention for the urban lakes, especially in the rural areas, and take some rules for real estate developers and residents.

DULAEM based on the ULMG and MAS-CA model reflects the natural factor and human factor for urban lake so that it can show the dynamic process of lake area change. Therefore, it would be significant for the policy-making of lake protection and the optimal configuration of land resources in the lakeside.

\section{Data Availability}

The data used to support the findings of this study are available from the corresponding author upon request.

\section{Conflicts of Interest}

The authors have no conflicts of interest related to this manuscript.

\section{Authors' Contributions}

Jianfeng Zhu performed data analysis and wrote the manuscript. Shenzhen Tian designed the study and assisted in data analysis.

\section{Acknowledgments}

This study was supported by the National Natural Science Foundation of China (no. 41671158), the Liaoning Province Natural Science Foundation Project (no. 2020-BS-182), Liaoning Province Philosophy and Social Science Planning Fund Project (no. L19CJY007), and the New Doctoral Research Initiation Project of Liaoning Normal University (no. 203070091901).

\section{References}

[1] S. Birch and J. McCaskie, "Shallow urban lakes: a challenge for lake management," Hydrobiologia, vol. 395/396, pp. 365-378, 1999.

[2] A. Martínez-Arroyo and E. Jáuregui, “On the environmental role of urban lakes in Mexico City," Urban Ecosystems, vol. 4, no. 2, pp. 145-166, 2000.

[3] T. Nakayama and M. Watanabe, "Role of flood storage ability of lakes in the Changjiang river catchment," Global and Planetary Change, vol. 63, no. 1, pp. 9-22, 2008.

[4] P. Snehal and P. Unnati, "Challenges faced and solutions towards conservation of ecology of urban lakes," International 
Journal of Scientific \& Engineering Research, vol. 3, no. 10, pp. 170-183, 2012.

[5] B. Fu, T. Tian, Y. Liu, and W. Zhao, "New developments and perspectives in physical geography in China," Chinese Geographical Science, vol. 29, no. 3, pp. 363-371, 2019.

[6] J. Lemoalle, J. C. Bader, M. Leblanc, and A. Sedick, "Recent changes in Lake Chad: observations, simulations and management options (1973-2011)," Global and Planetary Change, vol. 80-81, pp. 247-254, 2012.

[7] R. Ding, "The complex network theory-based urban land-use and transport interaction studies," Complexity, vol. 2019, 14 pages, 2019.

[8] Z. Zhang, F. Liu, X. Zhao et al., "Urban expansion in China based on remote sensing technology: a review," Chinese Geographical Science, vol. 28, no. 5, pp. 727-743, 2018.

[9] K. Xu, "Changes of urban wetlands in Wuhan, China, from 1987 to 2005," Progress in Physical Geography, vol. 34, no. 2, pp. 207-220, 2010.

[10] J. Wu and H. Xie, "Research on characteristics of changes of lakes in Wuhan's main urban area," Procedia Engineering, vol. 21, pp. 395-404, 2011.

[11] P. R. Leavitt, C. S. Brock, C. Ebel, and A. Patoine, "Landscapescale effects of urban nitrogen on a chain of freshwater lakes in central North America," Limnology and Oceanography, vol. 51, no. 5, pp. 2262-2277, 2006.

[12] L. L. Stahl, B. D. Snyder, A. R. Olsen, T. M. Kincaid, J. B. Wathen, and H. B. McCarty, "Perfluorinated compounds in fish from U.S. urban rivers and the Great Lakes," Science of the Total Environment, vol. 499, pp. 185-195, 2014.

[13] Z. Wang, "Study on protection and utilization of wuhan city lake since 1990s," Environmental Science \& Management, vol. 38, no. 6, pp. 38-45, 2013.

[14] B. J. Irvin, S. J. Ventura, and B. K. Slater, "Fuzzy and isodata classification of landform elements from digital terrain data in Pleasant Valley, Wisconsin," Geoderma, vol. 77, no. 2, pp. 137-154, 1997.

[15] X. Deng, C. Zhao, and H. Yan, "Systematic modeling of impacts of land use and land cover changes on regional climate: a review," Advances in Meteorology, vol. 2013, 11 pages, 2013.

[16] J. D. Miller, H. Kim, T. R. Kjeldsen, J. Packman, S. Grebby, and R. Dearden, "Assessing the impact of urbanization on storm runoff in a peri-urban catchment using historical change in impervious cover," Journal of Hydrology, vol. 515, pp. 59-70, 2014.

[17] H. Qin, "Water quality changes during rapid urbanization in the shenzhen river catchment: an integrated view of socioeconomic and infrastructure development," Sustainability, vol. 6, no. 10, pp. 1-19, 2014.

[18] K. Feeters, "The use of the normalized difference water index (NDWI) in the delineation of open water features," International Journal of Remote Sensing, vol. 17, no. 7, pp. 14251432, 1996.

[19] B. Cao, L. Kang, S. Yang, D. Tan, and X. Wen, "Monitoring the dynamic changes in urban lakes based on multi-source remote sensing images," in Geo-Informatics in Resource Management and Sustainable Ecosystem, GRMSE 2014. Communications in Computer and Information Science, F. Bian, Y. Xie, Eds., vol. 482, Springer, Berlin, Germany, 2015.

[20] J. Jia-Hu, D. Hong-Shen, and H. Qun, "Relational analysis of the features of resources and functions of lakes," Journal of Natural Resources, vol. 19, no. 3, pp. 386-391, 2007.
[21] P. Huang, "Study on evolution of urban lakes in Wuhan based on RS/GIS," Ecology \& Environmental Sciences, vol. 21, no. 9, pp. 1588-1593, 2012.

[22] S. Al Rawashdeh, R. Ruzouq, A. k. Al-Fugara, B. Pradhan, S. H. Ziad, and A. R. Ghayda, "Monitoring of dead sea water surface variation using multi-temporal satellite data and GIS," Arabian Journal of Geosciences, vol. 6, no. 9, pp. 3241-3248, 2013.

[23] S. Wolfram, "Universality and complexity in cellular automata," Physica D: Nonlinear Phenomena, vol. 10, no. 1-2, pp. 1-35, 1984.

[24] J. Yang, A. Guo, Y. Li, Y. Zhang, and X. Li, "Simulation of landscape spatial layout evolution in rural-urban fringe areas: a case study of Ganjingzi District," GIScience \& Remote Sensing, vol. 56, no. 3, pp. 388-405, 2019.

[25] J. J. Arsanjani, "Integration of logistic regression, Markov chain and cellular automata models to simulate urban expansion," International Journal of Applied Earth Observation and Geoinformation, vol. 21, pp. 265-275, 2013.

[26] H. S. Moghadam and M. Helbich, "Spatiotemporal urbanization processes in the megacity of Mumbai, India: a Markov chains-cellular automata urban growth model," Applied Geography, vol. 40, pp. 140-149, 2013.

[27] M. Al-shalabi, L. Billa, B. Pradhan, S. Mansor, and A. A. A. AlSharif, "Modelling urban growth evolution and land-use changes using GIS based cellular automata and SLEUTH models: the case of sana'a metropolitan city, Yemen," Environmental Earth Sciences, vol. 70, no. 1, pp. 425-437, 2013.

[28] M. Wooldridge and N. R. Jennings, "Intelligent agents: theory and practice," The Knowledge Engineering Review, vol. 10, no. 2, pp. 115-152, 1995.

[29] J. Yang, "Simulating intraurban land use dynamics under multiple scenarios based on fuzzy cellular automata: a case study of jinzhou district," Complexity, vol. 2018, Article ID 7202985, 17 pages, 2018.

[30] E. L. Karfopoulos and N. D. Hatziargyriou, "A multi-agent system for controlled charging of a large population of electric vehicles," IEEE Transactions on Power Systems, vol. 28, no. 2, pp. 1196-1204, 2013.

[31] A. T. Crooks, "Constructing and implementing an agentbased model of residential segregation through vector GIS," International Journal of Geographical Information Science, vol. 24, no. 5, pp. 661-675, 2010.

[32] Y. Liu, "Simulating the conversion of rural settlements to town land based on multi-agent systems and cellular automata," PLoS One, vol. 8, no. 11, Article ID e79300, 2013.

[33] R. Tan, Y. Liu, K. Zhou, L. Jiao, and W. Tang, "A game-theory based agent-cellular model for use in urban growth simulation: a case study of the rapidly urbanizing Wuhan area of central China," Computers, Environment and Urban Systems, vol. 49, pp. 15-29, 2015.

[34] A. Rienow and D. Stenger, "Geosimulation of urban growth and demographic decline in the Ruhr: a case study for 2025 using the artificial intelligence of cells and agents," Journal of Geographical Systems, vol. 16, no. 3, pp. 311-342, 2014.

[35] J. Yang, J. Su, F. Chen, P. Xie, and Q. Ge, "A local land use competition cellular automata model and its application," ISPRS International Journal of Geo-Information, vol. 5, no. 7, p. 106, 2016.

[36] H. Zhao, H. Wang, W. Wu, and C. Wang, "Integrated $3 S$ technology used in urban grid management, ISPRS - International Archives of the Photogrammetry," Remote Sensing and Spatial Information Sciences, vol. 2, pp. 1-5, 2014. 
[37] X. Wu, "An optimized infrastructure of VGE based on grid," Proceedings of SPIE-The International Society for Optical Engineering, vol. 5985, pp. 59850B-59851B, 2006.

[38] H. M. Rizeei, B. Pradhan, and M. A. Saharkhiz, "An integrated fluvial and flash pluvial model using 2D high-resolution subgrid and particle swarm optimization-based random forest approaches in GIS," Complex \& Intelligent Systems, vol. 5, pp. 283-302, 2019.

[39] L. Deren, Z. Xinyan, and G. Jianya, "From digital map to spatial information multi-grid," Geomatics and Information Science, vol. 28, no. 6, pp. 642-650, 2003.

[40] H. Luo, S. Spiegel, and R. Löhner, "Hybrid grid generation method for complex geometries," AIAA Journal, vol. 48, no. 11, pp. 2639-2647, 2010.

[41] H. Xu, "Modification of normalised difference water index (NDWI) to enhance open water features in remotely sensed imagery," International Journal of Remote Sensing, vol. 27, no. 14, pp. 3025-3033, 2006.

[42] J. Zhu, Q. Zhang, and Z. Tong, "Impact analysis of lakefront land use changes on lake area in wuhan, China," Water, vol. 7, no. 9, pp. 4869-4886, 2015.

[43] H. U. Wei-Yan and T. Liu, "Multi-scale Analysis on spatial differences of cultivated land occupied by construction in wuhan metropolitan area," China Land Sciences, vol. 31, no. 5, pp. 38-46, 2017. 